\title{
Measuring exchange rate misalignment in Turkey
}

\author{
Ü. Özlale \& E. Yeldan
}

To cite this article: Ü. Özlale \& E. Yeldan (2004) Measuring exchange rate misalignment in Turkey, Applied Economics, 36:16, 1839-1849, DOI: 10.1080/0003684042000279735

To link to this article: http://dx.doi.org/10.1080/0003684042000279735

央 Published online: 02 Feb 2007.

Submit your article to this journal

III Article views: 128

Q View related articles $\sqsubset$

47 Citing articles: 9 View citing articles 지 


\title{
Measuring exchange rate misalignment in Turkey
}

\author{
Ü. ÖZLALE* and E. YELDAN \\ Bilkent University, Department of Economics, Bilkent 06800, Ankara, Turkey
}

Turkey has embarked an extensive dis-inflation and stabilization program in December 1999. The programme exclusively relied on a nominally pegged (anchored) exchange rate system for dis-inflation and on fiscal austerity. In February 2001, however, Turkey experienced a severe financial crisis which necessiated the dismantling of the exchange rate anchor and a switch to a regime of free float.

This article proposes a new methodology to measure exchange rate misalignment for Turkey over the period January 1992 to December 2001. In a single equation framework, the model estimates the real exchange rate within a time varying parameter model, where a return-to-normality assumption about the parameters is assumed. Contrary to common belief, it is found that, except the initial four months of the stabilization programme, the Turkish lira remained undervalued for most of 2000. Also, one observes a pattern where the lira has been overvalued after the financial crisis of 1994 until 1998, and has displayed a tendency of undervaluation after then.

\section{INTRODUCTION}

Turkey initiated an extensive dis-inflation program in December 1999, backed and supervised by the International Monetary Fund (IMF). The programme exclusively relied on a nominally anchored exchange rate basket and fiscal austerity. In February 2001, however, in the midst of its implementation, Turkey experienced a sudden currency crisis, which deepened into a severe recession and has continued to-date. In what followed, the Central Bank was forced to sell a large portion of its foreign reserves in an attempt to support the Turkish lira (TL), and finally declared the surrender of the pegged exchange rate system on 22 February, thereby unconditionally switching to an exchange system of free float.

An important line of criticism on the 1999 Turkish disinflation programme was that it overlooked the structurally fragile characteristics of the banking system, and relied excessively on short-term capital flows for liquidity genera- tion. ${ }^{1}$ It further ignored the fact that the lira was already misaligned on the eve of the program's implementation in late 1999.

The lira's experience of free float throughout the rest of 2001 followed the general pattern of overshooting succeeded by stabilization, as was also witnessed during much of the currency crisis episodes of the emerging market economies in the 1990s. The nominal conversion rate of the lira vis-à-vis the US\$ depreciated by $86 \%$ by August 2001. Yet, after mild fluctuations until October, it virtually stabilized displaying a nominal stability. This occurred against the ongoing inflationary pressures with an average monthly rate of $3.7 \%$ in consumer prices, and $4.2 \%$ in producer prices between October 2001 and the time of writing.

This observation set forth a new line of argument claiming that the TL was again 'overvalued' and that competitiveness of Turkish exportables was at stake. Setting the ill-defined issue of the meaning of 'over'- or 'under'-

*Corresponding author. E-mail: ozlale@ bilkent.edu.tr

${ }^{1}$ The underlying elements of the disinflation program and the succeeding crisis are discussed in detail in Ertuğrul and Yeldan (2003), Akyüz and Boratav (2002), Yeldan (2002), Boratav and Yeldan (2002), Ertuğrul and Selçuk (2001), Eichengreen (2001), Gencay and Selçuk (2001), and Alper (2001). 
valuation of a currency under the workings of marketdetermined free float aside, the question is not trivial, as the currency crises witnessed among emerging economies throughout the 1990s clearly underscored the need for avoiding exchange rates that are incompatible with maintaining sustainable external accounts. After the Mexican, East Asian and the Argentinean crises in particular, international economists intensified their efforts to understand the behaviour and determinants of the real exchange rate in emerging market economies.

Conventionally, the real exchange rate is regarded as 'misaligned' if its realized value exhibits a persistent departure from its long run equilibrium trend. The long-run equilibrating value, in turn, is taken to be that rate which, for a given set of 'structural fundamentals' is compatible with simultaneous achievement of internal and external equilibrium. ${ }^{2}$ It is clear that such an assessment has to go beyond the simple PPP calculations which are wrought with issues of the choice of a relevant price index and a proper base year.

In fact, as noted by Evans and Lyons (2002), academic research on exchange rate determination has already been in a state of flux following the seminal papers of Meese and Rogoff (1983a, b). Furthermore, empirical findings on exchange rate misalignment (ERM henceforth) are controversial themselves, and suffer from limitations of simplistic assumptions, as mentioned in Edwards and Savastano (1999). As a result, the literature on exchange rate determination, which would serve us to come up with a model to measure ERM in a developing country such as Turkey has potential conflicts. Therefore, there is a need for unconventional approaches to find out the determinants of the real exchange rate and to measure ERM.

An alternative approach on exchange rate determination is to use data from the field of microstructure finance. Evans and Lyons (2002) move in an original direction and introduce the microeconomics of asset pricing. They use order flow data as one of the determinants of the exchange rate and argue that such a specification significantly improves the explanatory power of the model. They further discuss that order flow might be doing so well perhaps because it is capturing variation in other macro variables that are not reflected in observed statistics.

This article attempts to measure ERM in a single equation framework by using a mean reverting time-varying parameter model. To the authors' knowledge, such a methodology has not been employed before in the literature of ERM. Also, one takes into account the views put forth by Flood and Rose (1995) and Evans and Lyons (2002) by including new macro variables such as exchange rate volatility and banking sector's foreign capital flows. One argues that these new variables reveal important information, which order flow captures in Evans and Lyons (2002).

The plan of the article is as follows. Section II briefly summarizes the literature on ERM and single equation models, which dominated the field of ERM in the recent years. Following a brief review of the salient characteristics of the foreign exchange market in Turkey in Section III, the model is introduced, and its advantages are discussed in Section IV. After the estimation and interpretation of the results, we conclude in Section V.

\section{REVIEW OF LITERATURE ON ERM}

As Kaminsky et al. (1998) mentions, the overvaluation of exchange rates has been a potential predictor of currency crisis in emerging economies. Cottani et al. (1990) and Ghura and Grennes (1993) also found evidence for a strong positive relationship between ERM and lower economic growth. These findings suggest that there are potential gains from analyzing the dynamics of ERM.

The literature on ERM follows two distinct paths: PPPbased models and single equation models. Models using the PPP-based definitions of the equilibrium exchange rate are known to suffer from their lack of empirical fit in short and medium term horizons (Frenkel 1981, Meese and Rogoff $1983 \mathrm{a}$, b). Therefore, in recent years more emphasis is based on single equation models. Such models start with choosing a group of variables (often called fundamentals) that are assumed to affect the real exchange rate. Time series techniques are then used to estimate a real exchange rate equation, with the most common estimation method being a vector error correction model. Next, the fundamentals are decomposed into transitory and permanent components by an appropriate filter. After permanent components of the fundamentals are inserted into the estimated exchange rate equation, the resulting fitted time series is interpreted as the equilibrium real exchange rate. Finally, deviations between the estimated equilibrium rate and the actual real exchange rate yield the degree of structural misalignment of the model.

Although single equation models dominated the field of ERM in the recent years, they also have some shortcomings. These are discussed at length by Edwards (2001) and Edwards and Savastano (1999). First, these models implicitly assume that the real exchange rate is in a stable equilibrium during the period under the study, which need not be the case. Second, the role of debt accumulation and current account dynamics are often ignored. Also, as mentioned in Baum and Barkoulas (2001), error correction models, which are widely used in single equation models, may not be appropriate due to fractional behaviour in

\footnotetext{
${ }^{2}$ See Edwards (2001). See also Fischer (2001) on the formal statement of the problem within the context of a finer classification of the exchange rate systems.
} 
the disequilibrium term. Moreover, the banking sectors in many emerging countries breed volatile capital movements, which may significantly affect exchange rate dynamics in the domestic asset markets.

This study takes the above mentioned criticisms as its starting point and introduces a dynamic time series model to explain exchange rate misalignment in Turkey within a single-equation framework. After a rich set of fundamentals is employed, the appropriate model is chosen in terms of model selection criteria. A time varying parameter model, which would not face the problems of error correction models in single equation models, is selected next. After an equilibrium exchange rate series is obtained, the difference between the observed rate and the equilibrium rate determines the degree of exchange rate misalignment.

The advantages and possible shortcomings of employing such a model and the variables used will be discussed in Section IV below. One now turns to a brief discussion of the recent developments of the Turkish economy.

\section{PATTERNS OF THE TURKISH EXCHANGE RATE OVER THE 1990s}

Turkey adopted convertibility of the lira in early 1990. By then all foreign exchange transactions on the capital account were already liberalized. In retrospect, this move is regarded to be pre-mature and over-hasty. Without correcting for macro fundamentals and without taking the necessary steps to ensure prudential regulation of the banking sector, the domestic goods and asset markets felt undue strains in adjusting to the volatile conditions of open international competition. Boratav et al. (2002), Cizre-Sakallioğlu and Yeldan (2000), Öniş and Aysan (2001) and Yentürk (1999) for instance, point out that important fragility indicators such as the ratio of shortterm foreign debt to Central Bank reserves, and the standard ratios of financial deepening revealed that the Turkish foreign exchange market was not yet ready for graduation for opening up to the speculation of international arbiters.

One reports the main parameters affecting the Turkish foreign exchange market in Table 1. As can be seen, Turkey continued to display significant fragility with short term foreign debt to $\mathrm{CB}$ reserves ${ }^{3}$ exceeding $100 \%$, and $\mathrm{M} 2 \mathrm{Y}$ to $\mathrm{CB}$ reserves over $300 \%$.

To this fragile picture, an added set of pressures originated from the public sector's increased borrowing requirements (PSBR). In fact, with the advent of full-fledged financial liberalization after 1989, the PSBR financing relied exclusively on issues of government debt instruments (GDIs) to the internal market, especially the banking sector. The stock of domestic debt was only $6 \%$ of GNP in 1989. It grew rapidly and reached $42.8 \%$ in 1995 , and $59.1 \%$ in 2000 (Table 1).

Against this background, in December 1999 the Turkish government adopted a comprehensive dis-inflation programme, aiming at decreasing the inflation rate to a single-digit level by the end of 2002. Aided with the supervision and technical support of the IMF, the programme relied on exchange rate based dis-inflation and monetary control by setting upper limits on the net domestic asset position of the Central Bank (CB). Accordingly the $\mathrm{CB}$ committed itself to a policy of no sterilization, whereby changes in the monetary base would directly reflect changes in the net foreign assets of its balance sheet. The programme further entailed a series of austerity measures on fiscal expenditures and set specific targets for the surplus on non-interest, primary budget.

In what follows, the programme announced that the rate of currency depreciation would be set according to a preannounced calendar, thereby setting the course for the evolution of the exchange rate throughout the year. For this purpose, the $\mathrm{CB}$ declared an exchange rate basket consisting of 1 US $\$+€ 0.77$, and announced a daily calendar of depreciation rate which adds up to a cumulative $20 \%$ by the end of 2000. The pre-announcement of the exchange rate depreciation according to such a tablita was regarded as the backbone of the program in its attempt to break the inflationary inertia of three decades.

During the course of its implementation, the Turkish dis-inflation programme is observed to suffer from the unavoidable surge in private consumption, and together with the elimination of exchange rate risk, it was regarded as a clear sign for increased foreign borrowing. The rapid escalation of the stock of foreign debt mostly originated from increased short-term borrowing which, as under most circumstances, was exercised at a rate exceeding the social optimum. Given the fragile economic environment, the unsustainable character of short-term indebtedness, with the widening of the current account deficit throughout 2000 , led to a sudden capital outflow arid the surrender of the pegged exchange rate system in February 2001.

The lira's experience under the free float since February had been a significant depreciation until October 2001, followed by nominal stabilization since then. The nominal stabilization of the lira against an ongoing price inflation averaging $3 \%$ on a monthly basis brought questions of 'over' -valuation. With the Central Bank's declaration of 'instrument independence' for controlling inflation, and given its clear stance that it would not set targets for the exchange rate, producers of traded goods raised concerns of a loss of competitiveness. Yet, given that the purchasing power parity (PPP) comparisons of exchange rate

\footnotetext{
${ }^{3}$ Rodrik and Velasco (1999) regard this ratio as the most robust indicator of a currency crisis. For comparison, at the outbreak of the financial crisis in Asia in 1997, this ratio was $60 \%$ in Malaysia; $90 \%$ in Philippines; $150 \%$ in Thailand; and $170 \%$ in Indonesia.
} 
Table 1. Basic characteristics of the Turkish foreign exchange market, 1995-2001

\begin{tabular}{|c|c|c|c|c|c|c|c|}
\hline & 1995 & 1996 & 1997 & 1998 & 1999 & 2000 & 2001 \\
\hline Rate of change of the nominal exchange rate $(\mathrm{TL} / \$)$ & 54.0 & 77.0 & 86.6 & 71.7 & 60.6 & 49.3 & 95.8 \\
\hline \multicolumn{8}{|l|}{ Macroeconomic prices } \\
\hline Inflation (WPI) & 86.0 & 75.9 & 81.8 & 71.8 & 53.1 & 51.4 & 61.6 \\
\hline Inflation (CPI) & 89.1 & 79.3 & 85.7 & 84.6 & 64.9 & 54.9 & 54.4 \\
\hline Real interest rate on GDIs & 18.1 & 31.1 & 22.1 & 29.5 & 36.8 & -8.8 & 21.4 \\
\hline \multicolumn{8}{|l|}{ Real wage growth rates ${ }^{\mathrm{a}}$} \\
\hline Public sector & -17.1 & -25.0 & 19.1 & -1.3 & 42.0 & 6.9 & -11.5 \\
\hline Private sector & -8.3 & 1.9 & -3.0 & 16.9 & 11.6 & 1.0 & \\
\hline \multicolumn{8}{|l|}{ Real Rate of Growth } \\
\hline GDP & 7.2 & 7.0 & 7.5 & 3.1 & -5.0 & 7.2 & -9.5 \\
\hline Exports & 19.5 & 7.3 & 13.1 & 2.7 & -1.4 & 4.5 & 12.3 \\
\hline Imports & 53.5 & 22.2 & 11.3 & -5.4 & -11.4 & 34.0 & -26.0 \\
\hline \multicolumn{8}{|l|}{ As Ratio to the GNP (\%) } \\
\hline Current account balance & -1.4 & -1.3 & -1.4 & 1.0 & -0.7 & -4.8 & 1.4 \\
\hline Stock of foreign debt & 42.8 & 46.2 & 47.8 & 47.2 & 55.7 & 59.1 & 74.3 \\
\hline Budget balance & -4.0 & -8.3 & -7.6 & -7.0 & -11.6 & -10.9 & -15.6 \\
\hline PSBR & 5.2 & 8.8 & 7.6 & 9.2 & 15.1 & 12.5 & 15.9 \\
\hline \multicolumn{8}{|l|}{ Fragility Indicators } \\
\hline \multicolumn{8}{|l|}{ Short-term foreign debt / CB } \\
\hline International reserves $(\%)$ & 126.7 & 106.6 & 96.2 & 107.6 & 101.3 & 147.2 & 110.0 \\
\hline $\mathrm{M} 2 \mathrm{Y} / \mathrm{CB}$ inter.reserves $(\%)$ & 344.7 & 301.8 & 272.6 & 314.5 & 328.7 & 381.4 & 416.4 \\
\hline Currency substitution ${ }^{\mathrm{b}}$ & 54.8 & 50.9 & 48.6 & 45.1 & 45.2 & 44.1 & 56.2 \\
\hline Interest paym. on dom. debt/total tax revenues $(\%)$ & 43.9 & 59.2 & 41.7 & 61.0 & 66.4 & 63.7 & 103.4 \\
\hline Interest paym. on dom. debt/net new dom. borrowing (\%) & 93.7 & 83.1 & 63.5 & 97.9 & 87.5 & 137.8 & 47.2 \\
\hline Net new dom. borrowing/domestic debt stock $(\%)$ & 52.4 & 57.8 & 52.4 & 49.5 & 49.3 & 37.1 & 70.2 \\
\hline
\end{tabular}

Sources: SPO Main Economic Indicators; Undersecreteriat of Treasury, Main Economic Indicators

Notes: ${ }^{a}$ Data compiled from the Turkish Employers Association and the Confederation of Public Employers Unions, as reported in the Central Bank Annual Reports. Nominal wages are deflated using the CPI $(1994=100)$.

$\mathrm{b}$ (Rate of Dollarization): Ratio of foreign exchange deposits to total deposits of residents.

misalignment offer poor guidance, such claims had become a matter of unresolved controversy.

A particularly important unresolved issue in analyses of the PPP measure has been the choice of the proper base year. For instance, given the wholesale price index, choosing October 2001 as the base year reveals an 'overvaluation' of the TL by $27 \%$. If February 2001 is regarded as the base, the rate of overvaluation becomes $5.7 \%$. Per contra, using consumer rather than producer prices, we observe that lira is still 'under' -valued in comparison to its February 2001 value by $5.2 \%$. On a broader time horizon, if we look at the state of the lira in comparison to 1989 , -the year of capital account liberalization, one calculates an overvaluation of $18 \%$.

Figures 1, 2 and 3 display the paths of the index of the nominal value of the TL against the US\$ together with alternative price indexes assuming different base periods.

Our message from this review of recent events is clear: given a high inflationary environment embedded within financial and fiscal fragility, measuring exchange rate misalignment through simplistic PPP calculations offer poor guidance. For this task one needs the guidance of a proper model. This task is turned to in the next section.

\section{MODEL}

A mean-reverting time-varying parameter model is employed to measure ERM for Turkey. Such an approach has several desirable characteristics: The coefficients of the variables which determine the equilibrium real exchange rate are allowed to deviate from their sample mean over time. Therefore, the real exchange rate need not be in a stable equilibrium over the period considered. Such an approach will not face the criticism that Edwards (2001) and Edwards and Savastano (1999) make for singleequation models. The unpleasant characteristics of Error Correction Models mentioned in Baum and Barkoulas (2001) are also avoided in such a formulation. Finally, a richer set of fundamentals will likely to result in a more compact model to determine the equilibrium real exchange rate. Consequently, most of the important criticisms that authors bring for single equation models are not faced in our model.

\section{Time- varying parameter models}

Time-varying parameter models have been extensively used in the macroeconomics and finance literature (see 


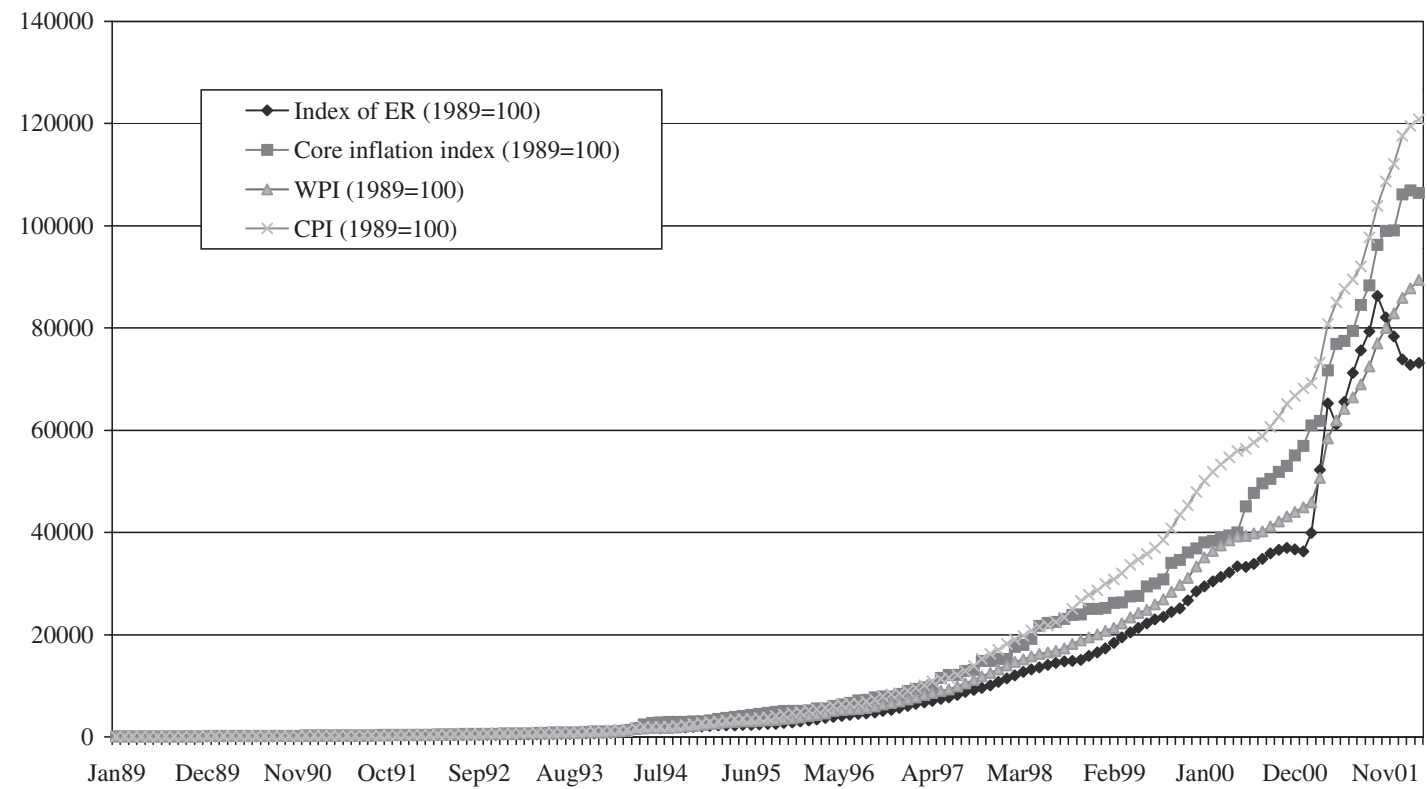

Fig. 1. Indexes of the exchange rate $(T L / \$)$ and prices $(1989=100)$

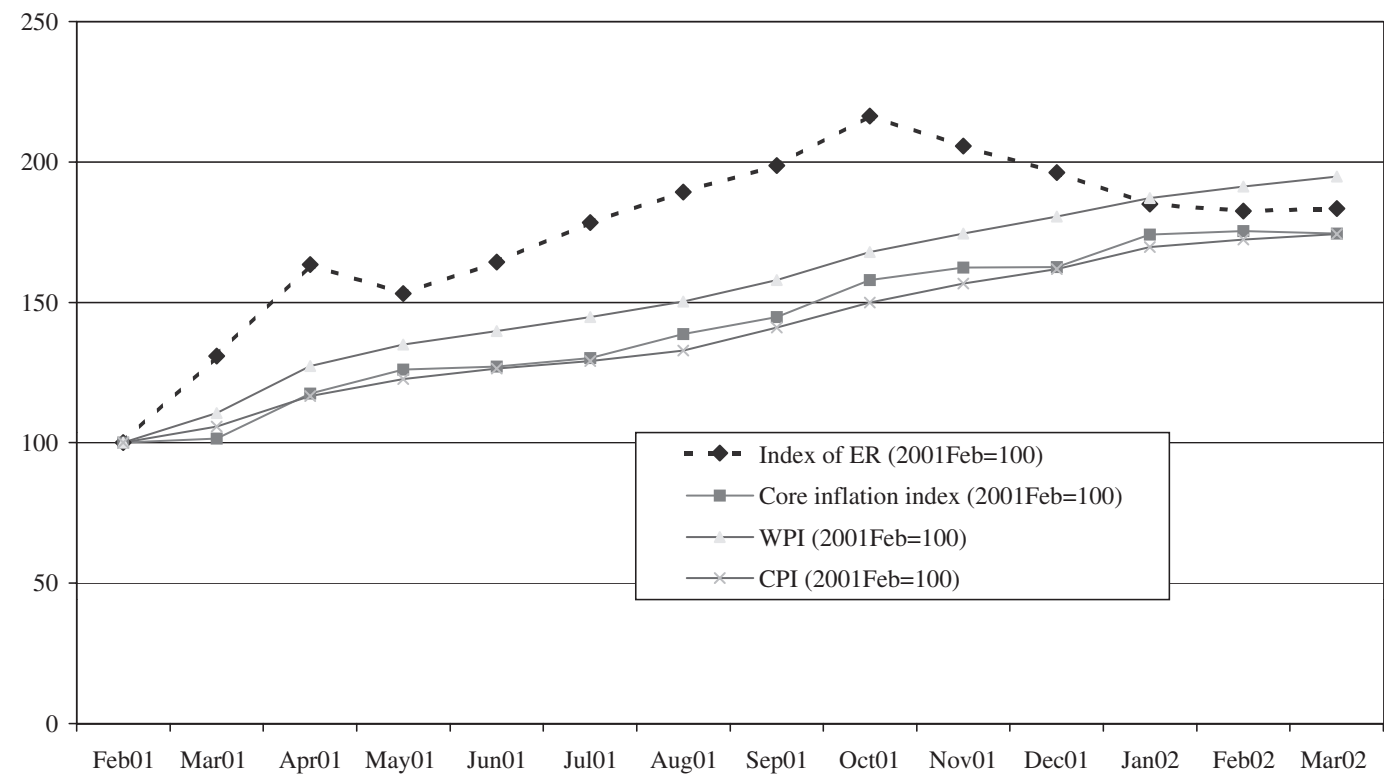

Fig. 2. Indexs of the exchange rate $(T L / \$)$ and prices $(2001 \mathrm{Feb}=100)$

Hamilton, 1994 for a detailed discussion and literature survey). These models are extensions of state space models where a powerful recursive algorithm, the Kalman Filter, is used for estimation purposes. The general form of such models is presented in Appendix 1.

The model that will be employed to measure exchange rate misalignment in this study is a mean-reverting timevarying parameter model, where the variables that are assumed to affect equilibrium real exchange rate have varying coefficients over time. Such a formulation allows us to track the changing effects of macro-based variables on the real exchange rate. Moreover, the difference between the estimated real exchange rate with changing parameters each period and the real exchange rate itself will give us a measure of exchange rate misalignment. The model can be summarized as:

$$
\begin{gathered}
y_{t}=X_{t}^{\prime} \beta_{t}+w_{t} \\
\left(\beta_{t+1}-\bar{\beta}\right)=F\left(\beta_{t}-\bar{\beta}\right)+v_{t+1}
\end{gathered}
$$

where $y_{t}$ is the real exchange rate, $X_{\mathrm{t}}$ is $(k \times 1)$ vector that includes the regressors. These regressors are lagged values of the real exchange rate, exchange rate volatility, shortterm capital movements and conventional macro variables. 


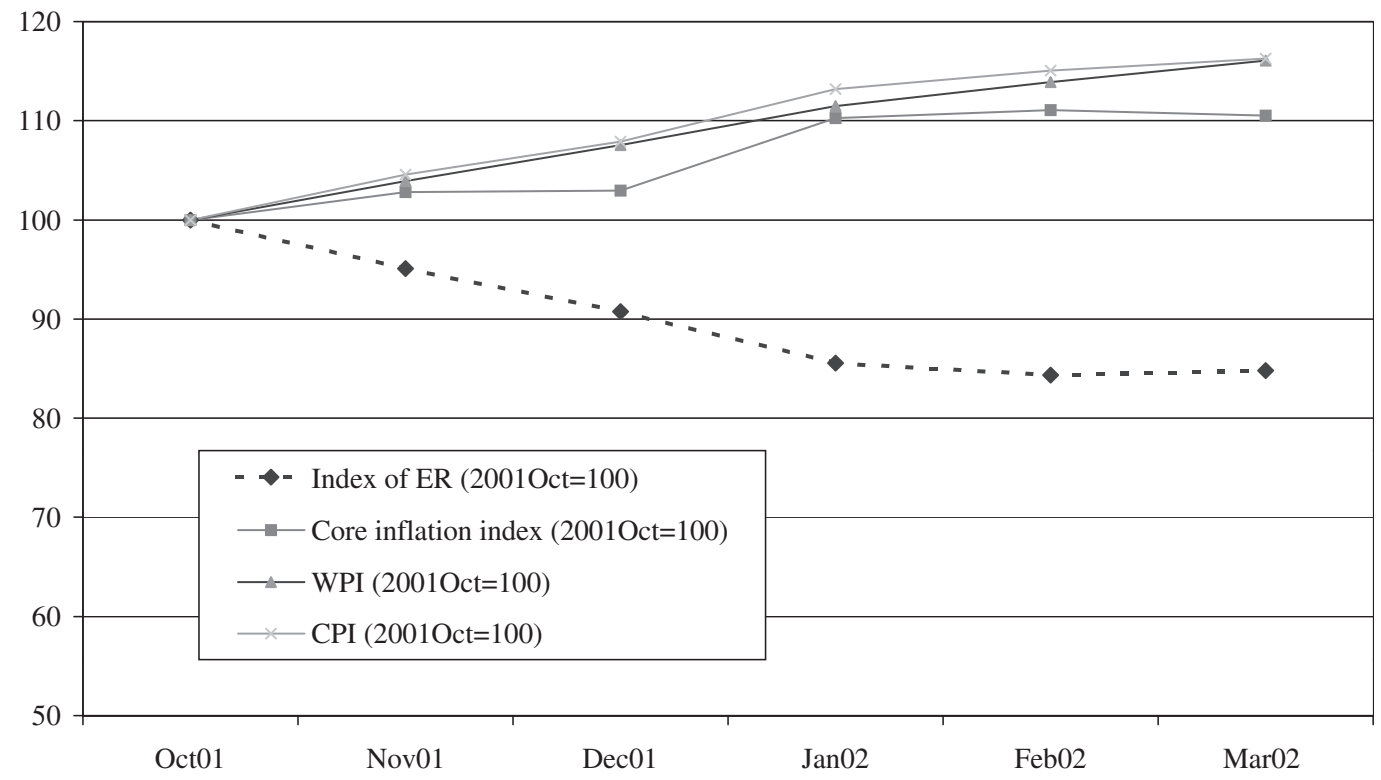

Fig. 3. Indexes of the exchange rate $(T L / U S \$)$ and prices (October 2001=100)

The regressors are assumed independent of $w_{\tau}$ for all $\tau$. The second equation is the state equation in state space models and implies that the deviations of the coefficients of the regressors from their sample means (their steady state values) follow an $\mathrm{AR}(1)$ process. ${ }^{4}$

If the eigenvalues of the $(k \times k)$ matrix $F$ are inside the unit circle, then $\bar{\beta}$ is the average (steady state) value for the coefficient vector. It is also assumed that

$$
\left[\begin{array}{c}
v_{t+1} \mid X_{t}, Y_{t-1} \\
w_{t}
\end{array}\right] \sim N\left(\left[\begin{array}{l}
0 \\
0
\end{array}\right],\left[\begin{array}{cc}
Q & 0 \\
0 & \sigma^{2}
\end{array}\right]\right)
$$

Then the last three equations are recognized as a state space model of the form with state vector $\xi_{t}=\beta_{t}-\bar{\beta}$. The regression can be written as:

$$
y_{t}=X_{t}^{\prime} \bar{\beta}+X_{t}^{\prime} \xi_{t}+w_{t}
$$

which is the observation equation of the form $y_{t}=a\left(X_{t}\right)+\left[H\left(X_{t}\right)\right]^{\prime} \xi_{t}+w_{t}$ with $a\left(X_{t}\right)=X_{t}^{\prime} \bar{\beta}, H\left(X_{t}\right)=X_{t}$ and $R\left(X_{t}\right)=\sigma^{2}$. Then, these values can be used in the Kalman Filter equations described in the appendix.

In this case, the log-likelihood function to be maximized will be:

$$
\begin{aligned}
\sum_{t=1}^{T} \log f\left(y_{t} \mid X_{t}, Y_{t-1}\right) \\
=-\frac{T}{2} \log (2 \pi)-\frac{1}{2} \sum_{t=1}^{T} \log \left(X_{t}^{\prime} P_{t \mid t-1} X_{t}+\sigma^{2}\right) \\
\quad-\frac{1}{2} \sum_{t=1}^{T}\left(y_{t}-X_{t}^{\prime} \bar{\beta}-X_{t}^{\prime} \hat{\xi}_{t \mid t-1}\right)^{2} /\left(X_{t}^{\prime} P_{t \mid t-1} X_{t}+\sigma^{2}\right)
\end{aligned}
$$

\section{Data and the estimation results}

All of the variables in our sample are monthly observations. The sample period is between January 1992 and December 2001. The variables used to perform the analysis include exchange rate volatility, short-term capital movements, industrial production index, inflation based on consumer price index, monthly budget balance of the public sector, openness, and lagged values of these variables.

Exchange rate volatility is obtained as the sum of squares of changes within a month. Openness is the ratio of the sum of exports and imports in the gross domestic product. For the short-term capital flows, (CREDIT) two alternative data specifications were implemented: monthly volume of gross versus net short-term foreign credit obtained by the banking sector. The distinction between gross versus net flows of foreign capital is not trivial, and our underlying motivation is to capture the differential impact of the CREDIT variable on the agents' perceptions of availability of short-term capital as well as the fragility embedded in its volatility. This distinction is convincingly emphasized in Tobin (2000: 1101-2) where he argues that it is only the net transfers that carry the economic benefits. (Yet) it is the gross, speculative transactions which carry with them the destabilizing effects leading to financial crises and severe real economic downturns. Given that exchange rate volatility is directly affected from the gross volume of capital flows and that currency appreciation is regarded as one of the key indicators of a culminating financial crisis

\footnotetext{
${ }^{4}$ Note that we can also generalize the state equation to a $p^{\text {th }}$ order, Vector Autoregression (VAR) for the coefficient vector $\beta_{\mathrm{t}}$ by defining $\xi_{t}^{\prime} \equiv\left[\left(\beta_{t}-\bar{\beta}\right)^{\prime},\left(\beta_{t-1}-\bar{\beta}\right)^{\prime}, \ldots,\left(\beta_{t-p+1}-\bar{\beta}\right)^{\prime}\right]$ and replacing the state equation accordingly.
} 
(see, e.g. Calvo and Vegh, 1999, Kaminsky et al., 1998), one finds it important to address both considerations by dinstinguishing two alternative modeling specifications over the CREDIT variable. For robustness check, one uses alternative measures for inflation, output and shortterm capital movements. In addition, current account measures are used, in line with the criticisms of Edwards (2001) and Edwards and Savastano (1999). However, the results remained robust.

The first step in the estimation process is to select the appropriate model to estimate the real exchange rate. Akaike Information Criteria (AIC) and Schwarz Information Criteria (SIC) were used for this purpose. Among many models estimated, the best model, which gave the lowest AIC and SIC values along with highest $R^{2}$ is found as:

$$
\begin{aligned}
\text { rer }_{t}= & \beta_{1 t} \text { rer }_{t-1}+\beta_{2 t} \text { rer }_{t-12}+\beta_{3 t} \text { ervol }_{t-1}-\beta_{4 t} \text { ip }_{t}+\beta_{5 t} i_{p_{t-1}} \\
& +\beta_{6 t} i_{t-12}+\beta_{7 t} \text { cpi } i_{t}+\beta_{8 t} \text { cpi }_{t-12}+\beta_{9 t} \text { Creditnet }_{t-1}+\varepsilon_{t}
\end{aligned}
$$

where $\operatorname{rer}_{t}$ is the real exchange rate at time $t$, ervol is the exchange rate volatility, $i p$ is the industrial production, $c p i$ is the inflation based on consumer price index, Creditnet is the short-term net capital flows. The simple OLS estimates for this equation along with the test statistics can be seen in Table 2. It is found that the above reduced form, which can be easily supported by a theoretical model, has a very good empirical fit.

Table 2 states that all variables employed are significant except the first lagged value of industrial production. Other than the first lagged value of the real exchange rate, the most important variable in determining the real exchange rate is exchange rate volatility, which also has the expected sign. An increase in the volatility of the real exchange rate in the last period leads to a depreciation of Turkish lira in the next period, most probably through an expectations channel. Another important finding is the relative unimportance

Table 2. OLS Estimates for the model

\begin{tabular}{lclr}
\hline Variable & Coefficient & Std. Error & $t$-stat \\
\hline rer $_{t-1}$ & 0.78 & 0.0489 & 15.92 \\
rer $_{t-12}$ & 0.164 & 0.0462 & 3.55 \\
ervol $_{t-1}$ & -0.519 & 0.2260 & -2.29 \\
ip $_{t}$ & 0.131 & 0.0587 & 2.23 \\
pp $_{t-1}$ & -0.046 & 0.0475 & 0.96 \\
ip $_{t-12}$ & -0.111 & 0.0557 & -1.99 \\
cpi & -0.392 & 0.1147 & -3.41 \\
cpi $_{t-12}$ & 0.227 & 0.1168 & 1.94 \\
creditnet $_{t}$ & 0.001 & 0.0008 & 1.87 \\
\hline
\end{tabular}

Notes: $R^{2}: 0.87$

Adjusted $R^{3}: 0.86$

AIC $: 5.09$

SIC $: 5.31$

F- statistic : 84.98 of net short-term capital movements. Although it is statistically significant at $10 \%$ significance level, its effect on real exchange rate is negligible.

Appendix 2 documents the efforts for checking the robustness of the model together with alternative specifications of Equation 3. The findings reveal that the analysis embedded in Equation 3 is robust to the implementation of several alternative variables as regressors (see Appendix 2).

The next step is to formulate the state space system and obtain a time series for each coefficient. The state space system can be written as:

$$
\begin{gathered}
\text { rer }_{t}=X_{t}^{\prime} \beta_{t}+w_{t} \\
\left(\beta_{t+1}-\bar{\beta}\right)=F\left(\beta_{t}-\bar{\beta}\right)+v_{t+1}
\end{gathered}
$$

where $X_{t}$ is the $9 \times 1$ vector of regressors. As mentioned above, one assumes that the coefficients evolve according to return to normality process.

After the state space system is estimated via the Kalman Filter, the predicted series for each of the nine coefficients are obtained. However, since one uses lagged values in estimating the real exchange rate equation there are fewer than 120 observations for the coefficient series.

The next step is to generate an implied real exchange rate. This is achieved by multiplying each period's coefficient vector with the regressor vector. Then, in the final phase, the difference between the real exchange rate and the generated (implied) real exchange rate $\left(\right.$ grer $\left._{t}\right)$ gives the level of the exchange rate misalignment based on the structure of the model.

Formally, $\mathrm{erm}_{t}=\mathrm{rer}_{t}-\mathrm{grer}_{t}$, where erm denotes the exchange rate misalignment. If $\mathrm{erm}<0$, then it means that the Turkish lira is undervalued; and it is said to be overvalued when erm $>0$. The graph for erm can be seen in Fig. 4.

\section{Overview of results and policy lessons}

The results indicate that following the crisis in 1994, the Turkish lira remained mostly overvalued until the beginning of 1998, in the aftermath of the Asian crisis. After then, an undervalued lira was observed until the end of 1999. At that point, the negative effects of the Russian crisis and the August 1999 earth-quake are worth mentioning. In December 1999, the IMF-backed dis-inflation program was introduced. An unavoidable currency appreciation was expected and was, in fact, targeted to combat inflationary expectations at early stages of the programme. However, one finds that the lira was actually overvalued only during the first four months of 2000 , while the rest of the year witnessed undervaluation of the lira. This finding is contrary to the common wisdom based on simple PPP calculations. The sizable devaluation of the Turkish lira can easily be seen in February 2001, when the currency crisis took place and the disinflation program was 


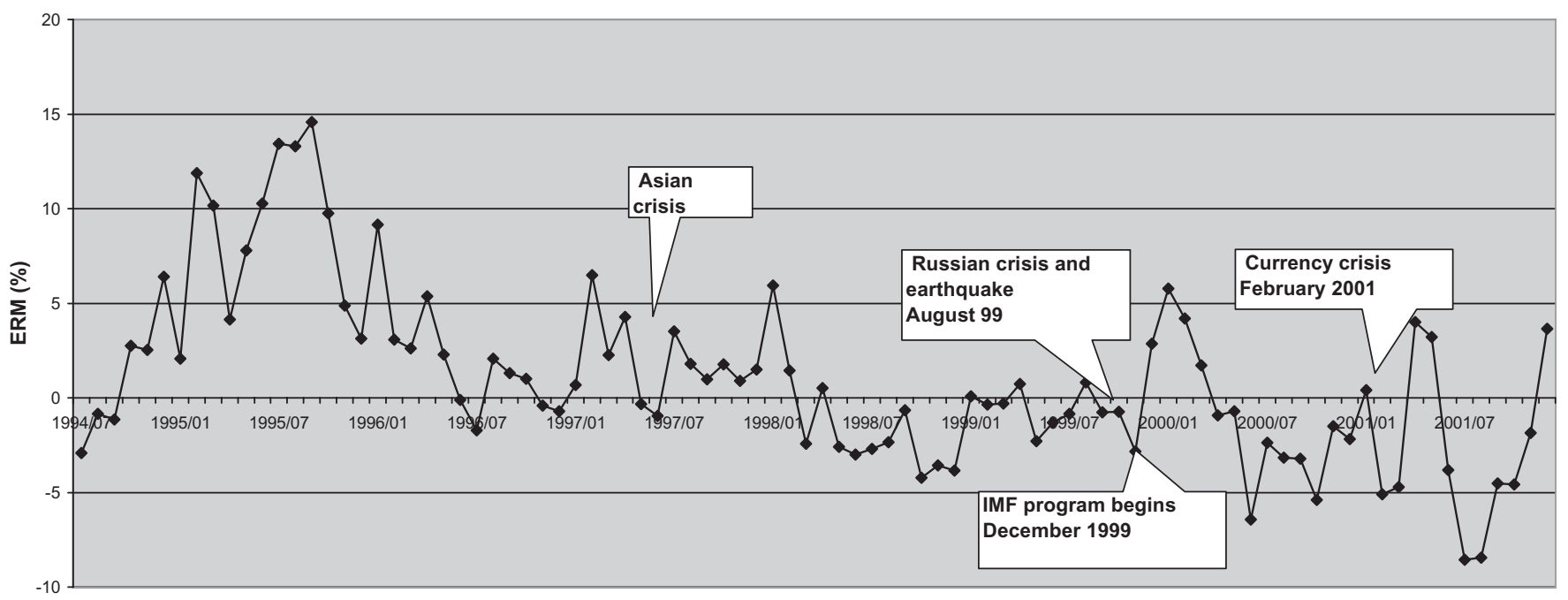

Fig. 4. Exchange rate Misalignment in Turkey

officially abandoned. The degree of undervaluation was at its peak during July and August of 2001. Finally, in the latest observation, one sees that the lira began to appreciate and enter an overvaluation phase by the end of 2001. It seems that the nominal stabilization of the lira following October of 2001 has revealed itself as a misalignment (overvaluation) late in December.

An important source of the unexpected behaviour of the TL during the implementation of the dis-inflation programme lies in the interaction of the deepening financial and fiscal fragility indicators along with the key macroeconomic prices, a phenomenon which the simple PPP measures fail to capture. In the first two quarters of 2000 , Turkish GDP had increased by $5.5 \%$ and $6.8 \%$, respectively. These rates were scored over the $-5.0 \%$ rate of growth of 1999. Given the strong growth performance of the GDP and other macro aggregates, the demand for TL seem to have generated strong pulls towards its appreciation in the first few months of 2000.

However, as highlighted in Table 1, the dis-inflation programme of 2000 had rested its economic balances on a very unstable macroeconomic environment and on a quite shallow and fragile financial base. In this context, one of the important elements of the culminating process of external fragility regards the path of the ratio of short-term foreign debt to Central Bank's international reserves. One observes that the disinflation programme had actually deepened the fragility as signalled in this indicator with a rise to $112 \%$ in June, and to $147 \%$ by December of 2000 . This level was the highest score since 1993, just before the 1994 financial crisis. Yet, the designers of the dis-inflation program had envisaged that possible increases in CB reserves would be able to match the increase in outstanding short term foreign debt, and that Turkey would be able to remain sound externally. However, all of this deterioration in the external accounts would in fact be realized in spite of the US billions reserve assistance obtained from the IMF in late November 2000. Yet all this generous external support would not suffice to generate stability to the domestic macro environment, and the Turkish asset markets would drift to the worst economic crisis in its history in February of 2001 .

Another indicator of external fragility of the 2000 disinflation programme was realized in the current account balance of the domestic economy. The ratio of the current account deficit to the Central Bank's international reserves was on the order of $5.9 \%$ by the end of 1999 . This indicator had been on a continuous worsening trend throughout 2000 , and increased to $28 \%$ in June, and to $49.7 \%$ by the end of the year. As a ratio to the GNP, the deficit in the current account reached to $5 \%$ in 2000 , from its modest level of $0.7 \%$ in 1999 . Thus, the dis-inflation programme had been implemented under the initial conditions of a relatively stable external environment, had resulted in a severe deterioration of the external balances of the Turkish economy through the course of 2000. Given a rational expectations framework, the perceptions of the economic agents on an increasingly vulnerable lira seem to have generated pressures for undervaluation of the currency in the remaining months of 2000 .

This finding further explains one of the most puzzling aspects of the 2000 dis-inflation episode in Turkey, namely the persistent demand for foreign exchange in residents' portfolios. Throughout 2000, contrary to all official expectations, private deposit holders were observed to be quite reluctant to switch from their foreign denominated (for-ex) accounts into the TL accounts. The ratio of foreign exchange deposits to total deposits of residents, for instance, stood at $44.1 \%$ in 2000 . This ratio, often regarded as one of the key indicators of currency substitution 
(dollarization), was $45.2 \%$ in 1999 , and 45.1 in 1998 . Furthermore, during the same period, coupled with the sudden drop of the risk premium, the real interest rates (on GDIs) fell to negative values (of $-8.8 \%$, see Table 1). Thus, given the structural undervaluation of the TL, the residents were observed to maintain their portfolio composition, quite rationally, in favor of the for-ex accounts.

\section{CONCLUSION}

The purpose of this article was to come up with a measure for real exchange rate misalignment for Turkey, which has already undergone a severe economic crisis. We argued that the conventional PPP models can not successfully explain the dynamics of exchange rate, at least in the short and medium run. Single equation models are proposed as an alternative in order to construct a measure of exchange rate misalignment. However, these models also have shortcomings, as highlighted in the literature. Thus, this article has taken these criticisms as its starting point and employed a time-varying parameter model within a single equation framework for Turkey. One assumed a return to normality assumption about the parameters, and generated an implied real exchange rate series by multiplying the parameter vector with the regressor vector for each period. Then, the difference between the real exchange rate and the implied rate provided us with a measure of exchange rate misalignment.

It is found that, following the economic crisis in 1994, the Turkish lira was overvalued for four consecutive years. Then, excluding the first four months of 2000 and the short period of April 2001 and May 2001, one observes an undervalued Turkish lira. The nominal standstill of the lira starting October 2001 gave way to overvaluation only late in the year, by December 2001. The results were interpreted in the context of rational agents having information on the deeping fragility of the Turkish macroeconomic environment throught the implementation of the dis-inflation programme and the ensuing crisis after February 2001. It is a matter of availability of new data to answer whether Turkish lira continues to be overvalued in 2002 and beyond.

\section{ACKNOWLEDGEMENTS}

The authors would like to thank Christopher Baum, Refet Gurkaynak, Faruk Selçuk, the participants of the 6th METU Conference on Economics, September 2002, Ankara and the colleagues at Bilkent University for their criticisms and suggestions on earlier drafts of the article. The authors are also grateful to Gül Biçer for her excellent research assistance.

\section{REFERENCES}

Akyüz, Y. and Boratav, K. (2002) The making of the Turkish financial crisis, mimeo, http://www.bagimsizsosyalbilimciler. org/yazilar/AkyuzBoratav.htm.

Alper, E. (2001) The Turkish liquidity crisis of 2000: what went wrong?, Russian and East European Finance and Trade, 37, $51-71$.

Baum, C. and Barkoulas, J. (2001) Dynamics of intra-EMS interest rate linkages, Boston College Department of Economics Working paper No. 492.

Boratav, K. and Yeldan, E. (2002) Turkey, 1980-2000: financial liberalization, macroeconomic (in)-stability, and patterns of distribution, CEPA and The New School for Social Research, mimeo, Bilkent University, Department of Economics.

Boratav, K., Yeldan, E. and Köse, A. (2002) Turkey: globalization, distribution and social policy, 1980-1998, in External Liberalization, Economic Performance and Social Policy (Ed.) L. Taylor. Oxford University Press, Oxford.

Cizre-Sakallioğlu, Ü. and Yeldan, E. (2000) Politics, society and financial liberalization: Turkey in the 1990s, development and change, 31, 481-508.

Calvo, G. and Vegh, C. (1999) Inflation stabilization and BOP crises in developing countries, in Handbook of Macroeconomics (Eds) J. Taylor and M. Woodford, North Holland, Amsterdam, pp. 1531-614.

Cottani, J., Cavallo, D. and Khan, M. S. (1990) Real exchange rate behavior and economic performance in LDCs, Economic Development and Cultural Change, 39, 61-76.

Edwards, S. (2001) Exchange rate regimes, capital flows and crisis prevention, NBER Working Paper No. 8529.

Edwards, S. and Savastano, M. A. (1999) Exchange rates in emerging economies: what do we know? What do we need to know?, NBER Working Paper No. 7228.

Eichengreen, B. (2001) Crisis prevention and management: any new lessons from Argentina and Turkey?, Background paper for the World Bank's Global Development Finance, 2002.

Ertuğrul, A. and Selçuk, F. (2001) A brief account of the Turkish economy, 1980-2000, Russian and East European Finance and Trade, 37, 6-28.

Ertuğrul, A. and Yeldan, E. (2003) On the structural weakness of the post-1999 Turkish disinflation program, Turkish Studies, 4.

Evans, M. and Lyons, C. (2002) Order flow and exchange rate dynamics, Journal of Politcal Economy, 110, 170-80.

Fischer, S. (2001) Exchange rate regimes: is the bipolar view correct?, Journal of Economic Perspectives, 15, 3-24.

Flood, R. and Rose, A. (1995) Fixing exchange rates: a virtual quest for fundamentals, Journal of Monetary Economics, 36, 3-37.

Frenkel, J. (1981) Collapse of purchasing power parities during the 1970s, European Economic Review, 16, 145-65.

Ghura, D. and Grennes, T. (1993) The real exchange rate and macroeconomic performance in sub-saharan africa, Journal of Development Economics, 42, 155-74.

Gencay, R. and Selçuk, F. (2001) Overnight borrowing, interest rates and extreme value theory, Bilkent University, Department of Economics Discussion Paper No 01-03, March.

Hamilton, J. (1994) Time Series Analysis, Princeton University Press, Princeton, NJ.

Kaminsky, G., Lizondo, S. and Reinhart, C. (1998) Leading indicators of currency crises, IMF Staff Papers, 45, 1-48.

Meese, R. and Rogoff, K. (1983a) Empirical exchange rate models of the Seventies, Journal of International Economics, 14, 3-24. 
Meese, R. and Rogoff, K. (1983b) The out-of-sample failure of empirical exchange rate models, in Exchange Rate and International Macroeconomics (Ed.) J. Frenkel. University of Chicago Press, Chicago.

Öniş, Z. and Aysan, A. (2000) Neoliberal Globalization, the nation state and financial crises in the semi-periphery: a comparative analysis, Third World Quarterly, 21.

Rodrik, D. and Velasco, A. (1999) Short-term capital flows, Proceedings of the Annual World Bank Conference on Development Economics, 59-90, The World Bank, Washington, DC.

Tobin, J. (2000) Financial globalization, World Development, 28, $1101-04$

Yeldan, E. (2002) On the IMF-directed disinflation program in Turkey: a program for stabilization and austerity or a recipe for impoverishment and financial chaos? in The Ravages of Neo-Liberalism: Economy, Society and Gender in Turkey (Ed.) N. Balkan, Nova Science, New York.

Yentürk, N. (1999) Short-term capital inflows and their impact on macroeconomic structure: Turkey in the 1990s, The Developing Economies, 37, 89-113.

\section{APPENDIX 1}

Time-varying parameter models

Time-varying parameter models can be written as:

$$
\begin{aligned}
\xi_{t+1} & =F\left(X_{t}\right) \xi_{t}+v_{t+1} \\
y_{t} & =a\left(X_{t}\right)+\left[H\left(X_{t}\right)\right]^{\prime} \xi_{t}+w_{t}
\end{aligned}
$$

where the first equation is called as the state equation and the second one is the observation equation. $F\left(X_{t}\right)$ is a $r \times r$ matrix whose elements are functions of $X_{t} ; a\left(X_{t}\right)$ is an $n \times 1$ vector-valued function, and $H\left(X_{t}\right)$ is an $r \times n$ matrix-valued function. Let $Y_{t-1} \equiv\left(y_{t-1}^{\prime}, y_{t-2}^{\prime}, \ldots, y_{1}^{\prime}, X_{t-1}^{\prime}\right.$, $\left.X_{t-2}^{\prime}, \ldots, X_{1}^{\prime}\right)^{\prime}$. Then, the disturbance vector $\left(v_{t+1}^{\prime}, w_{t}^{\prime}\right)^{\prime}$ has the following distribution:

$$
\left[\left(\begin{array}{c}
v_{t+1} \\
w_{t}
\end{array}\right) \mid X_{t}, Y_{t-1}\right] \sim N\left(\left[\begin{array}{l}
0 \\
0
\end{array}\right],\left[\begin{array}{cc}
Q\left(X_{t}\right) & 0 \\
0 & R\left(X_{t}\right)
\end{array}\right]\right)
$$
It follows from the above equations that $\left[\left(\xi_{t} \mid X_{t}, Y_{t-1}\right)\right]$
is normally distributed as:

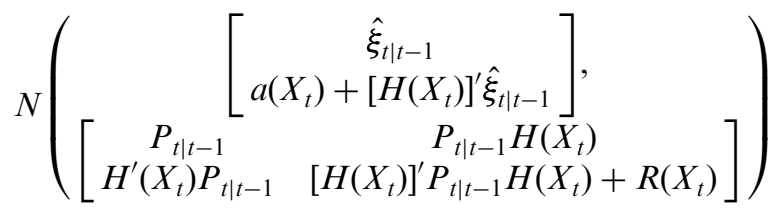

Finally, in order to estimate the parameters of the system, one executes the Kalman Filter, which can be defined by the following updating equations:

$\hat{\xi}_{t \mid t}=\hat{\xi}_{t \mid t-1}+\left\{\begin{array}{c}P_{t \mid t-1} H\left(X_{t}\right)\left[\left(H\left(X_{t}\right)\right]^{\prime} P_{t \mid t-1} H\left(X_{t}\right)+R\left(X_{t}\right)\right]^{-1} \\ \times\left[y_{t}-a\left(X_{t}\right)-\left[H\left(X_{t}\right)\right]^{\prime} \hat{\xi}_{t \mid t-1}\right]\end{array}\right\}$

$$
\begin{aligned}
& P_{t \mid t}+P_{t \mid t-1}-\left\{P_{t \mid t-1} H\left(X_{t}\right)\left[\left[H\left(X_{t}\right)\right]^{\prime} P_{t \mid t-1} H\left(X_{t}\right)+R\left(X_{t}\right)\right]^{-1}\right. \\
& \left.\quad \times\left[H^{\prime}\left(X_{t}\right) P_{t \mid t-1}\right]\right\}
\end{aligned}
$$

Since $\hat{\xi}_{t+1 \mid t} \mid y_{t} \sim N\left(\hat{\xi}_{t+1 \mid t}, P_{t+1 \mid t}\right)$ where

$$
\begin{aligned}
& \hat{\xi}_{t+1 \mid t}=F\left(X_{t}\right) \hat{\xi}_{t \mid t} \\
& P_{t+1 \mid t}=F\left(X_{t}\right) P_{t \mid t}\left[F\left(X_{t}\right)\right]^{\prime}+Q\left(X_{t}\right)
\end{aligned}
$$

These last four equations constitute the Kalman filter equations.

\section{APPENDIX 2}

\section{Robustness check and alternative specifications}

To understand whether the results presented above is sensitive to alternative specifications, the analysis was performed using several other variables. One used current account measures along with monthly GDP and monthly inflation based on wholesale price index, as alternatives to variables ip and cpi. Moreover, one included two other measures of net short term capital movements.

One important result of this exercise regards the significance of short-term gross capital inflows as an alternative to net capital flows. Such a finding supports the insight put forth by Tobin (2000). Also, it is worth mentioning that the effect of exchange rate volatility has decreased and its significance was reduced dramatically when gross capital inflows was used in the regressor vector. The state space system is also estimated by taking the model in Table 3 as the observation equation. However, the loglikelihood of the model was found to be much lower than that of the original specification and most of the coefficients turned out to be not statistically significant.

Finally, two alternative specifications about the evolution of the parameters of the model were estimated.

Table 3. Alternative model

\begin{tabular}{lclr}
\hline Variable & Coefficient & Std. Error & $t$-stat \\
\hline rer $_{t-1}$ & 0.826 & 0.0486 & 16.97 \\
rer $_{t-12}$ & 0.113 & 0.0453 & 2.50 \\
ervol $_{t-1}$ & -0.260 & 0.2378 & -1.09 \\
ip $_{t}$ & 0.105 & 0.0596 & 1.76 \\
ip $_{t-1}$ & 0.049 & 0.0475 & 1.04 \\
ip $_{t-12}$ & -0.086 & 0.0569 & -1.51 \\
cpi $_{t}$ & -0.385 & 0.1157 & -3.32 \\
cpi $_{t-12}$ & 0.332 & 0.1111 & 2.98 \\
credits $_{t}$ & 0.302 & 0.1399 & -2.16 \\
credits $_{t-1}$ & -0.338 & 0.1418 & \\
\hline
\end{tabular}

$R^{2}: 0.71$

Adjusted $R^{2}: 0.69$

AIC : 6.09

SIC $: 6.31$

F- statistic : 84.98 
These specifications assume 'random walk', and 'constant mean', respectively. These can be formulated as:

$$
\begin{aligned}
\text { Random walk: } \beta_{t+1} & =F \beta_{t}+\eta_{t} \\
\text { Constant mean : } \beta_{t+1} & =F \bar{\beta}+\eta_{t}
\end{aligned}
$$

After the system is estimated with each of these specifications, it is observed that the system with random walk assumption had a very high negative likelihood value, which makes it inferior to the original model. Also, the estimated exchange rate misalignment using the 'random walk' assumption predicted deviations of very small magnitude than the real exchange rate, which reduces its plausibility. On the other hand, the estimation with the 'constant mean' assumption was cumbersome, and no reasonable results could be obtained due to a singular matrix in the Kalman filter updating equation.

As a consequence, the above analysis reveals that the original specification presented in the previous subsection is robust to the presence of several alternative variables, and it gives the most reasonable results when compared with other models assuming 'random walk' and 'constant mean' assumptions about the evolution of the parameters over time. 